\title{
Climate-driven enrichment of pollutants in peatlands
}

\author{
A. Martínez Cortizas ${ }^{1}$, H. Biester ${ }^{2}$, T. Mighall ${ }^{3}$, and R. Bindler ${ }^{4}$ \\ ${ }^{1}$ Dept. Edafología y Química Agrícola, Universidad de Santiago de Compostela, Campus Universitario s/n, 15782 Santiago \\ de Compostela, Spain \\ ${ }^{2}$ Institute of Environmental Geochemistry, University of Heidelberg, INF 23669120 Heidelberg, Germany \\ ${ }^{3}$ Department of Geography and Environment, School of Geosciences, University of Aberdeen, Elphinstone Road, Aberdeen, \\ AB24 3UF, UK \\ ${ }^{4}$ Dept. of Ecology and Environmental Science, Umeå University, S901 87 Umeå, Sweden
}

Received: 6 June 2007 - Published in Biogeosciences Discuss.: 27 June 2007

Revised: 24 September 2007 - Accepted: 18 October 2007 - Published: 25 October 2007

\begin{abstract}
Peatlands play an important role for global carbon dynamics, acting as a sink or source depending on climate. Such changes imply a series of additional effects because peatlands are also an important reservoir of atmospherically derived pollutants. Using a multiproxy approach (non-pollen-palynomorphs, $\delta^{15} \mathrm{~N}, \mathrm{C} / \mathrm{N}, \mathrm{Se}, \mathrm{Br}, \mathrm{I}, \mathrm{Hg}, \mathrm{Ti}$ ), we show a relationship between climate (wetter-drier) and peat decomposition, which affected element concentrations in a Spanish bog during the last 5500 years. Changes in superficial wetness played a critical role in the cycling of elements coupled to carbon dynamics. Dry phases caused increased peat mineralisation, resulting in a 2-3 times increase in concentrations of the analysed elements independent from atmospheric fluxes. Under the present trend of climate change large areas of northern peatlands are expected to be severely affected; in this context our findings indicate that the increase in carbon release, which leads to an enrichment of elements, may enhance the export of stored contaminants $(\mathrm{Hg}$, organohalogens) to the aquatic systems or to the atmosphere.
\end{abstract}

\section{Introduction}

Peatlands cover about 5-8\% of the earth's continental surface and contain one third of the total soil carbon stock (IPCC, 2000), playing an important role in the carbon cycle. Depending on climatic conditions they may act as sinks or sources of carbon and other elements. A strong connection between climate and the global carbon cycle at the millenial scale was found to be mediated in part by carbon dynamics in peatlands, with carbon sequestration rates being highly sensitive even to minor climatic fluctuations (Yu et al., 2003). It has been estimated that at present the sink component is dominant, but recent modelling studies for boreal areas sug-

Correspondence to: A. Martínez Cortizas

(edantxon@usc.es) gest that about $60 \%$ of all peatland area in Canada and a similar proportion in North Eurasia will be severely to extremely severely affected by climate change (Gorham, 1991; Tarnocai and Stolbovoy, 2006), leading to a higher release of carbon dioxide and methane to the atmosphere.

Although the predicted increase in temperature may enhance peat decomposition, the changes in hydrology coupled to changes in precipitation patterns and permafrost thawing are expected to have the highest impact (Tarnocai and Stolbovoy, 2006). In peatlands organic matter turnover is highest in the upper aerated layers, where as much as $80 \%$ of the initial plant remains are mineralised and released as $\mathrm{CO}_{2}$ or dissolved organic matter (DOM) (Worral et al., 2001; Reynolds and Fenner, 2001; Freeman et al., 2004). In the lower sections the decay rate decreases by two or three orders of magnitude due to the anoxic conditions and usually low $\mathrm{pH}$, as well as by the inhibitory effect of the accumulation of some chemical substances like phenols (Kalviäinen and Karunen, 1984; Freeman et al., 2001). Although a slight release of carbon continues, the peat in the anoxic layers suffers only minor further degradation.

The cycle of biophyle elements $(\mathrm{C}, \mathrm{N}, \mathrm{P}$ and $\mathrm{S})$ in peatlands has been the target of many studies (Ohlson, 1987; Ohlson and Økland, 2002), but not much is known about the cycling of other elements, particularly those of environmental concern such as toxic heavy metals like mercury. Elements are incorporated into peatlands by wet and dry atmospheric deposition (the dominant pathway in ombrotrophic mires, by definition), as well as by groundwater and surface runoff (in minerogenic mires). Once incorporated as solutes or particles, elements can be retained through plant uptake, physical entrainment, complexation by humified organic matter, or through enzymatic microbial mediated formation of organic species. Some elements can also be rereleased to the atmosphere through evasion or to the hydrosphere in solution or coupled to DOM release. But the impact of present climate change on the accumulation/release

Published by Copernicus Publications on behalf of the European Geosciences Union. 
of elements from peatlands to the atmosphere and aquatic ecosystems is still largely uncertain.

Heavy metals, particularly $\mathrm{Pb}$ and $\mathrm{Hg}$, have been extensively investigated in peat cores to reconstruct long-term variations of their fluxes to the mires and thus to trace atmospheric pollution (Lee and Tallis, 1973; Shotyk, 1998; Martínez Cortizas et al., 2002). These investigations have rarely considered the role played by climate in the control of the deposition fluxes or the modification of element concentrations induced by changes in peat degradation (Biester et al., 2003, 2004, 2007).

In this study we compare climate variations since the middle Holocene $(\sim 5500 \mathrm{yrs})$ observed in a Spanish peatland with records of organically bound (e.g., $\mathrm{Se}, \mathrm{Br}, \mathrm{I}, \mathrm{Hg}$ ) and lithogenic (Ti) elements. We aim to show that the geochemistry of peat is strongly related to climatically controlled carbon dynamics and that the geochemical record in peat was sensitive to Holocene climate changes. Our findings for past climatic changes, contextualized with present scenarios of climate change, may enable a better understanding of the role peatlands play in the global biogeochemical cycles of elements (nutrients and pollutants).

\section{Material and methods}

We investigated a peat core from Pena da Cadela (PDC), an oceanic ombrotrophic mire located on a mountain summit at $970 \mathrm{~m}$ of altitude in the Xistral Mountains (NW Spain), for historical records of trace elements (mercury, bromine, iodine, selenium, and titanium) and peat decomposition ( $\mathrm{C}$ and $\mathrm{N}$ concentrations, $\mathrm{C} / \mathrm{N}$ ratios and $\left.\delta^{15} \mathrm{~N}\right)$. The core is $185 \mathrm{~cm}$ deep and has accumulated during the last 5500 cal. years BP. Sampling of the core, sample preparation as well as the records of some elements, such as $\mathrm{Pb}$, are discussed elsewhere (Martínez Cortizas et al., 2002). The ombrotrophic nature of the bog is supported by 1) its location on a blanket mire complex; 2) the smooth microtopography, with hummocks of less than $10 \mathrm{~cm}$ in height; 3) low bulk densities (average $0.11 \pm 0.02 \mathrm{~g} \mathrm{~cm}^{-3}$ ) and low ash content (average $2.8 \pm 1.4 \%) ; 4)$ acidic to strongly acidic peats ( $\mathrm{pH}$ in water 3.5-4.3, $\mathrm{pH}$ in $\mathrm{CaCl}_{2} 3.0-3.2$ ); 5) $\mathrm{Ca} / \mathrm{Mg}$ molar ratios similar to lower than those of the local rainfall water; and 6) very low concentrations of lithogenic elements ( $\mathrm{Ti}$ average concentration is $172 \pm 59 \mu \mathrm{g} \mathrm{g}^{-1}$ ) (Martínez Cortizas et al., 2002, 2005; Pontevedra Pombal et al., 2006). Present-day vegetation is dominated by sedges (Carex durieui, C. vulgaris, C. panicea, Eleocharis multicaulis) and grasses (Agrostis curtisii, A. hesperica, Molinia caeruluea, Deschampsia flexuosa, Eriophorum angustifolium), with presence of some heathers (Erica mackaiana and E. cinerea) (Fraga Vila, 2001; Fraga et al., 2005; Romero et al., 2005).

Bromine, selenium and titanium were measured using an energy dispersive miniprobe multielement XRF analyzer - its application to peat measurements is discussed in
Cheburkin and Shotyk (1998). Mercury was determined in freeze-dried samples by means of solid-phase thermal combustion atomic absorption spectrometry (LECO-Altec AMA254); while iodine was determined following the procedure described by Biester et al. (2004). Carbon and nitrogen were analysed by means of a LECO- $10000 \mathrm{CNH}$. $\delta^{15} \mathrm{~N}$ was obtained by mass spectrometry.

\section{Results and discussion}

\subsection{A link to climate change}

In a study of three bogs from NW Spain Mighall et al. (2006) identified humidity changes (wet and dry phases) in the last 5500 years by correlating biological and geochemical proxies. They found that variations of non-pollen palynomoprhs (NPPs T18 and T306) detected in two bogs (Borralleiras BLL-, and Pena da Cadela -PDC) were related to precipitation variations, based on the ecology of the proxies. A geochemical proxy, based on the proportion of $\mathrm{Hg}$ of intermediate thermal stability that was previously related to a humidity component in a third bog (Penido Vello, PVO; Martínez Cortizas et al., 1999), was also synchronous with the variations of the biological proxies. Although changes in peatland surface wetness are not necessarily indicative of changes in climate but to water table-depth (which may be affected by other factors than climate alone, i.e. peat growth), Mighall et al. (2006) attributed the variations in NPPs to precipitation changes because the location of the bogs (in mountain tops) enabled only for atmospheric deposition (wet and dry) and since the three separate bogs responded synchronously they had to be subjected to the same external forcing.

Figure 1a shows the records of the non-pollen palynomorphs (NPPs) T18 and T306, and $\delta^{15} \mathrm{~N}$ and $\mathrm{C} / \mathrm{N}$ ratios in a core sampled at PDC, the bog located at higher altitude ( $970 \mathrm{~m}$ a.s.1.) and which seems to have been the most sensitive in recording the changes in rainfall of those sites previously studied. The NPPs show intense changes during the last 5500 years, which indicate alternating wet (high T18 and low T306 abundances) and dry (low T18 and high T306 abundances) climate periods. There are five main wet phases in this peat record at $150-160 \mathrm{~cm}, 130-138 \mathrm{~cm}, 114-126 \mathrm{~cm}$, $84-100 \mathrm{~cm}$ and $32-64 \mathrm{~cm}$, which correspond to ca. 3950 3590 , ca. $3090-2790$, ca. $2580-2260$, ca. $1760-1430$ and ca. $1030-530 \mathrm{yr}$ cal BP, respectively. The duration of each of these wet phases was about 300-360 years except for the most recent one that may have lasted 500 years. The wet and dry phases are coeval with increased fluvial activity in Spain (Gutiérrez-Elorza and Peña-Monné, 1998; Thorndycraft and Benito, 2006), but opposite to those found for central and western Europe based on lake-level reconstructions (Magny,1999, 2004; Arnaud, et al., 2005; Holzhauser et al., 2005) or plant macrofossil remains in peat records (Hughes et al., 2000). This supports the hypothesis proposed by 

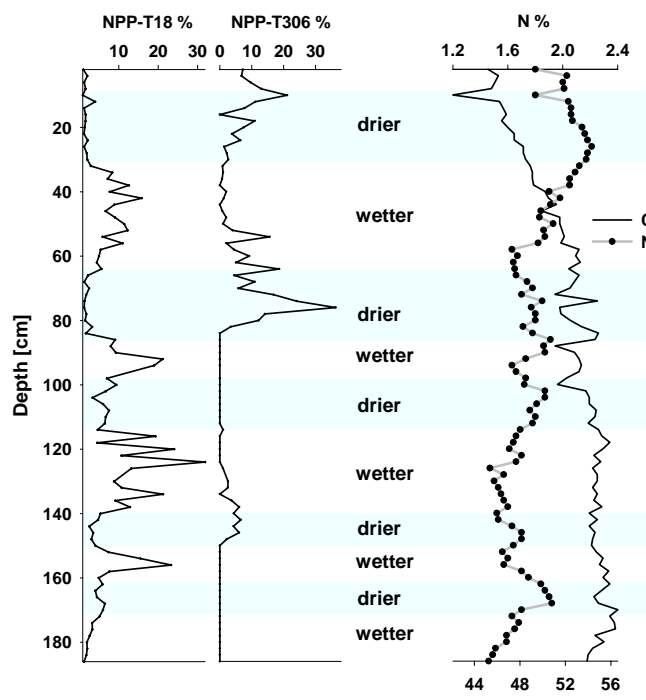

(a)
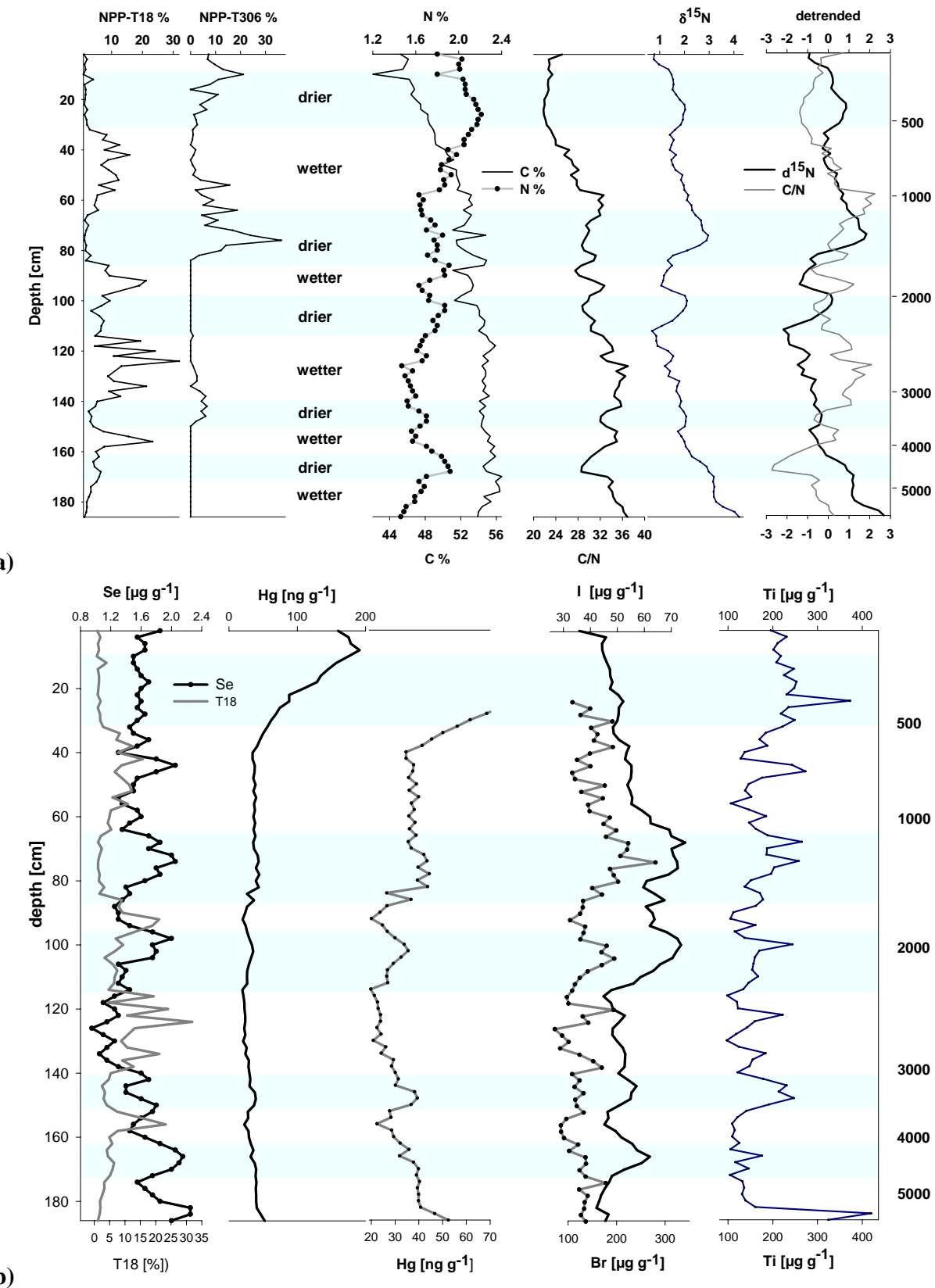

$\mathrm{C} / \mathrm{N}$

(b)
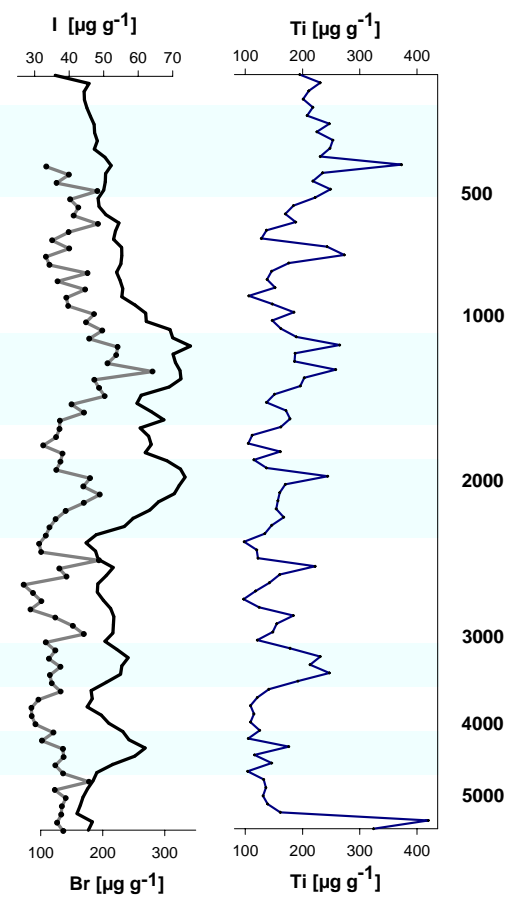

Fig. 1. (a) Records of NPPs T18 and T306 (after Mighall et al., 2006), and $\delta^{15} \mathrm{~N}$ and $\mathrm{C} / \mathrm{N}$ ratios in the PDC core. The detrended C/N ratios were calculated by substracting the $\mathrm{C} / \mathrm{N}$ ratio of individual peat slices to the long-term trend modelled by a linear regression equation and are expressed as standardized residuals. (b) Concentrations records of organically-bound ( $\mathrm{Br}, \mathrm{I}, \mathrm{Se}$ and $\mathrm{Hg}$ ) and lithogenic (Ti) elements in

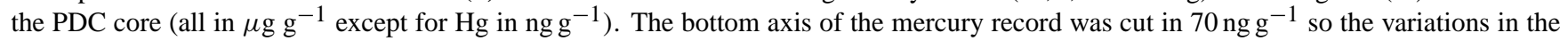
deeper sections of the core are observable.

Magny et al. (2003) that Holocene cooling in the North Atlantic Ocean coincided with drier conditions in southern (and northern) Europe.

In order to extract information on climatic effects on peat decomposition it is necessary to remove the secondary changes imposed by the gradual, long-term diagenetic effects that occur in the buried peat. For example, there is a general increase in the $\mathrm{C} / \mathrm{N}$ ratio from around 20 in the surface peat to 37 at the base of the PDC core that is caused by the preferential mineralization of $\mathrm{N}$ relative to $\mathrm{C}$ during organic matter diagenesis, which has been shown in other ombrotrophic bogs from the same area (Pontevedra Pombal, 2004) and 
documented in other studies for a number of sedimentary environments including ombrotrophic bogs (Herczeg, 1988; Updegraff et al., 1995; Khury and De Vitt, 1996). In Figure 1a we have detrended both the $\mathrm{C} / \mathrm{N}$ ratio and $\delta^{15} \mathrm{~N}$ records and expressed them as standardized residuals $\left(\delta^{15} \mathrm{~N}_{\text {detrend }}\right.$ and $\mathrm{C} / \mathrm{N}_{\text {detrend }}$, respectively). $\delta^{15} \mathrm{~N}_{\text {detrend }}$ and $\mathrm{C} / \mathrm{N}_{\text {detrend }}$ have a generally inverse behaviour with higher $\delta^{15} \mathrm{~N}_{\text {detrend values }}$ corresponding to relatively lower $\mathrm{C} / \mathrm{N}_{\text {detrend }}$. Low $\mathrm{C} / \mathrm{N}_{\text {detrend }}$ values are indicative of more decomposed and humified peat, while higher $\delta^{15} \mathrm{~N}$ values are indicative of higher $\mathrm{N}$ fractionation. The decomposition of the organic matter preferentially mineralizes ${ }^{14} \mathrm{~N}$, causing an enrichment in ${ }^{15} \mathrm{~N}$ and thus in $\delta^{15} \mathrm{~N}$ (Létolle, 1980; Macko et al., 1993).

The variations in $\delta^{15} \mathrm{~N}_{\text {detrend }}$ and $\mathrm{C} / \mathrm{N}_{\text {detrend }}$ coincide with the changes in climate (wetter-drier) as indicated by the biological climate proxies (NPPs). Wetter phases are character-

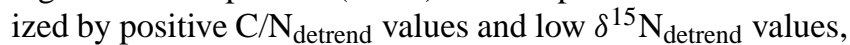
whereas drier phases show the opposite - the decline in $\mathrm{C} / \mathrm{N}$ ratios and increase in $\mathrm{N}$ fractionation are indicative of peat decomposition/mineralisation. In fact, the degree of humification of the peat was found to be a proxy for wet/dry cycles (Blackford and Chambers, 1993; Caseldine et al., 2000; Roos-Barraclough et al., 2004). Under saturated conditions oxygen availability in the peat is reduced, which inhibits the phenoloxidase enzyme activity controlling phenol accumulation (Freeman et al., 2001). Increased phenol accumulation under saturated conditions restricts the biological degradation of the organic matter; specifically, the elevated phenol concentrations restrain the activity of hydrolitic enzymes responsible for peat decomposition. In contrast, during dry periods when the water table is lower and formerly saturated peat levels are aerated, enzyme activity increases and promotes peat degradation. In ombrotrophic mires oxygen availability is connected to water table depth, which in turn depends on effective precipitation and thus on changes to wetter or cooler climates (Aaby, 1976; Barber, 1981; Chambers and Charman, 2004; Mauquoy et al., 2002).

\subsection{Variations in element concentrations}

The concentration records of the organically bound $(\mathrm{Br}, \mathrm{I}$, $\mathrm{Se}$ and $\mathrm{Hg}$ ) and lithogenic (Ti) elements are quite similar (Fig. 1b), with the only exception of $\mathrm{Hg}$ in the upper peat sections. The concentrations of bromine, selenium and titanium in the PDC core vary by $2.5-3$ times $\left(\mathrm{Br}: 120-350 \mu \mathrm{g} \mathrm{g}^{-1}\right.$; Se: $0.9-2.2 \mu \mathrm{gg}^{-1}$; Ti: $\left.100-250 \mu \mathrm{g} \mathrm{g}^{-1}\right)$, while mercury and iodine concentrations vary by $12-17$ times $(\mathrm{Hg}$ : $19-$ $230 \mathrm{ng} \mathrm{g}^{-1}$; I: $3-50 \mu \mathrm{gg}^{-1}$ ). Below $36 \mathrm{~cm}$ the variation in mercury concentration is only 3.5 -fold, which is comparable to those of bromine and selenium, suggesting that mercury must be influenced by anthropogenic emissions in the upper section of the peat core as found in other peat records in the area (Martínez Cortizas et al., 1999). Notwithstanding this exception, the records of the analyzed elements show a remarkable similarity. The ocean is the main source of atmo- spheric selenium, bromine and iodine (Kabata-Pendias and Pendias, 1992; Görres and Frenzel, 1993), which are mostly incorporated into the bog through wet deposition. For example, concentrations of bromine in peat and pore waters have been used to trace differences in sea spray inputs (Shotyk, 1997), thus assuming a direct relationship with atmospheric fluxes - mainly wet deposition. Mercury deposition is also dominated by the wet component, and the oceans contribute to mercury emissions to the atmosphere, although there is an additional strong terrestrial source (weathering and degassing of the Earth's crust) (Schroeder and Munthe, 1998; Scholtz et al., 2003). $\mathrm{Hg}^{0}$, the predominant form in the atmosphere, has a mean residence time of about one year and it is subject to long-range transport (Mason et al., 1994; Nriagu y Pacyna, 1988; Schroeder and Munthe, 1998; Scholtz et al., 2003).

The similarity between the records of the organicallybound elements suggests a common source or deposition mechanism. However, titanium, a conservative lithogenic element whose source is atmospheric dust deposition, also shows remarkably synchronous changes in concentration. Because the deposition of atmospheric aerosols increases in dry periods and decreases during wet periods (Mouline et al., 1997; Prospero and Lamb, 2003), the simultaneous increase in the concentration of organically bound and lithogenic elements is counterintuitive and has to be influenced by another factor than atmospheric deposition alone.

The comparison of the concentration records of selenium, bromine, iodine, mercury and titanium (Fig. 1b) with the climatic reconstruction reveals that, in the PDC core, elevated concentrations of these elements are found in sections corresponding to drier climate periods with greater humifica-

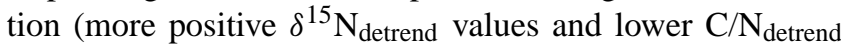
values), whereas lower concentrations correspond to wetter periods with less-degraded peat (low $\delta^{15} \mathrm{~N}$ values and high $\mathrm{C} / \mathrm{N}$ ratios). The elevated element concentrations are not the result of increased wet deposition, but instead indicate a relationship between the degree of peat transformation, i.e., decomposition, and the variations in the concentration of the elements. We do find a strong correlation between carbon accumulation and the accumulation of organically bound elements. The correlations between the net accumulation of carbon and selenium, bromine, iodine and mercury (excluding the top $30 \mathrm{~cm}$ impacted by pollution) are highly significant $\left(\mathrm{r}^{2}=0.9\right.$; data not shown $)$. For the organically bound elements this is a consistent result, because selenium, bromine, iodine and mercury all have a high affinity for binding to organic matter and are therefore usually enriched in organic-rich soils (Kabata-Pendias and Pendias, 1992; Görres et al., 1993; Biester et al., 2003). Selenium and mercury can form complexes with organic matter by abiotic mechanisms (Zhang and Moore, 1996; Xia et al., 1999), particularly when specific functional groups are availabe (e.g. S-groups for $\mathrm{Hg}$ ). Bromine and iodine are retained in organic matter through formation of organohalogens by 
oxygen-dependent enzymatic processes involving haloperoxidases (Gribble, 2003; Keppler and Biester, 2003) and are enriched during the decomposition of the organic matter (Myneni, 2002; van Pée and Unversucht, 2003). Some authors have suggested that halogens in peat are fixed by organic matter, and recent studies have demonstrated that they exist mostly as halogenated organic compounds (Biester et al., 2004).

The coincidence of increased peat decomposition and higher titanium concentrations may also be indicative of wet/dry cycles, but for completely different reasons. Higher peat decomposition is typical of dry periods during which enhanced soil erosion and dust deposition on the bog surface are likely, which would result in higher titanium concentrations. However, a residual enrichment of titanium could also result from the degradation of the organic matter, i.e., a loss of substrate.

We suggest that changes in climate, here expressed as variations in wetness or dryness, exerted a fundamental control on the evolution of the decomposition of the peat at the surface of the bog and consequently on the concentrations of many elements. The lowering of the water table during dry periods increased the oxygenation of the superficial peat layer and triggered/enhanced microbial decomposition. This not only resulted in an increase in mineralisation but also in humification, enhancing the potential for metal and halogen retention (Meili, 1991; Mierle and Ingram, 1991; Yin et al., 1996). Thus, the increase in decomposition and humification and the enrichment of metals and halogens are concurrent processes.

Contrary to what is commonly assumed changes in concentrations, at least for organically bound elements, seem to depend to a larger extent on internal transformations of the peat matrix and related mass loss, and not on variations of atmospheric fluxes alone as some have suggested (Shotyk, 1997). This result is also consistent to that found at greater spatial scales for soil organic horizons and supports the hypothesis that the enrichment of organically bound elements is also biologically mediated and climate dependent and would change with factors such as temperature and rainfall (Reimann and de Caritat, 2005). Other factors such as plant cover and composition, and bog microtopography have been reported to affect the accumulation of elements in peat (Olfield et al., 1979; Norton et al., 1997), although we think these factors didn't played a significant role in the PDC bog.

\section{Conclusions}

Here, we have shown that there has been a clear relationship between climate (wetter-drier) and peat decomposition and its effect on element concentrations in a Spanish bog during the last 5,500 years. Our findings have important implications for present day wetland environments. Projected changes in climate, particularly in areas of increased summer dryness, will increase rates of peat decomposition and thus loss of carbon as both $\mathrm{CO}_{2}$ and DOC. During subsequent wetter periods dissolved organic matter, which is enriched in pollutants, may be exported to surface waters. An increased export of dissolved organic matter related to droughts has in fact already been observed in some rivers draining peatlands (Worral and Burt, 2007). The relationship between the release of DOC and that of arganically bound elements from peat has been shown to occur for iodine and bromine (Biester et al., 2006). The surface layers of many bogs are artificially enriched in many metals, such as mercury, because of historical pollutant deposition and increased decomposition will magnify these already elevated concentrations. We speculate that $\mathrm{Hg}$, due to its affinity to bind to organic complexes might be increasingly released from peatlands as $\mathrm{Hg}$ DOC complexes. The changes we report here are from a mid-latitude bog, but the changes in carbon loss are expected to be much greater in the vast peatlands found at higher latitudes, particularly in permafrost areas that are or will be affected by severe thawing. Current climate research is focused largely on carbon dynamics, but these changes imply a series of additional effects. For example, a release of contaminants presently stored in high-latitude peatlands would exacerbate the current concern for high-latitude pollution.

Acknowledgements. We thank A. Cheburkin, X. PontevedraPombal and E. Peiteado for helping with sampling and analytical work. XRF measurements were done at the RIAIDT facility of the University of Santiago de Compostela, and $\mathrm{N}$ isotopic composition was analyzed at the Servicio de Apoyo a la Investigación of the Universidad Pública de Navarra. Financial support for this study was obtained from the Spanish Ministerio de Educación y Ciencia (project REN2003-09228-C02-01) and of the Xunta de Galicia (project PDIT03PXIB20002PR).

Edited by: T. R. Christensen

\section{References}

Aaby, B.: Cyclic variations in climate over the past 5,500 years reflected in raised bogs, Nature, 263, 281-284, 1976.

Arnaud, F., Revel, M., Chapron, E., Desmet, M., and Tribovillard, N.: 7200 years of Rhône river flooding activity in lake Le Bourget, France: a high-resolution sediment record of NW Alps hydrology, The Holocene, 15, 420-428, 2005.

Barber, K. E.: Peat Stratigraphy and Climate Change, Balkema, Rotterdam, 1981.

Biester, H., Keppler, F., Putschew, A., Martínez-Cortizas, A., and Petri, M.: Halogen retention, organohalogens, and the role of organic matter decomposition and halogen enrichment in two Chilean peat bogs, Environ. Sci. Technol. 38, 1984-1991, 2004.

Biester, H., Martínez-Cortizas, A., Birkenstock, S., and Kilian, R.: Effect of peat decomposition and mass loss on historic mercury records in peat bogs from Patagonia, Eviron. Sci. Technol., 37, 32-39, 2003.

Biester, H., Selimovic, D., Hemmerich, S., and Petri, M.: Release of halogens from peat bogs - The role of peat decomposition 
and dissolved oprganic matter (DOM), Biogeosciences, 3, 5364, 2006,

http://www.biogeosciences.net/3/53/2006/.

Biester, H., Bindler, R., Martínez Cortizas, A., and Engstrom, D. E.: Modeling the past atmospheric deposition of mercury using natural archives, Environ. Sci. Technol. 41, 8451-4860, 2007.

Blackford, J. J. and Chambers, F. M.: Determining the degree of peat decomposition in peat-based palaeoclimatic studies, Intern. Peat J., 5, 7-24, 1993.

Caseldine, C. J., Baker, A., Charman, D. J., and Hendon, D. A.: Comparative study of optical properties of $\mathrm{NaOH}$ peat extracts: implications for humification studies, The Holocene, 10, 649658,2000

Chambers, F. M. and Charman, D. J.: Holocene environmental change: contributions from the peatland archive, The Holocene, 14, 1-6, 2004.

Cheburkin, A. K. and Shotyk, W.: An Energy-dispersive Miniprobe Multielement Analyzer (EMMA) for direct analysis of $\mathrm{Pb}$ and other trace elements in peats, Fress, J. Anal. Chem., 354, 688691, 1996.

Fraga Vila, I.: Vegetación característica de las turberas de Galicia, in: Turberas de Montaña de Galicia, Xunta de Galicia, santiago de Compsotela, edited by: Martínez Cortizas, A. and GarcíaRodeja Gayoso, E., Colección Ténica Medio Ambiente, Chapter 6, 79-98, 2001.

Fraga Vila, I., Romero, D., and Sahuquillo, E.: Patterns of vegetation in relation to environmental conditions in Northwestern Spanish mires, IMCG Mires and Peatlands Field Symposium, Tierra del Fuego 2005, Argentina, 35-36, 2005.

Freeman, C., Fenner, N., Ostle, N. J., Kang, H., Dowrick, D. J., Reynolds, B., Lock, M. A., Sleep, D., Hughes, S., and Hudson, J.: Export of dissolved organic carbon from peatlands under elevated carbon dioxide levels, Nature, 430, 195-198, 2004.

Freeman, C., Ostle, N., and Kang, H.: An enzymatic latch on a global carbon storage, Nature, 409, 149, 2001.

Gorham, E.: Northern peatlands: Role in the carbon cycle and probable responses to climatic warming, Ecological Applications, 1, 182-195, 1991.

Görres, M. and Frenzel, B.: The $\mathrm{Pb}, \mathrm{Br}$, and $\mathrm{Ti}$ content in peat bogs as indicator for recent and past depositions. Naturwissenschaften, 20, 333-335, 1993.

Gribble, G. W.: The diversity of naturally produced organohalogens, Chemosphere, 52, 289-297, 2003.

Gutiérrez-Elorza, M. and Peña-Monné, J. L.: Geomorphology and late Holocene climatic change in Northeastern Spain, Geomorphology, 23, 205-217, 1998.

Herczeg, A. L.: Early diagenesis of organic matter in lake sediments: a stable carbon isotope study of pore waters, Chem. Geol., 72, 199-209, 1988.

Holzhauser, H., Magny, M., and Zumbühl, H. J.: Glacier and lakelevel variations in west-central Europe over the last 3500 years, The Holocene, 15, 789-801, 2005.

Hughes, P. D. M., Mauquoy, D., Barber, K. E., and Langdom, P. G.: Mire-development pathways and palaeoclimatic records from a full Holocene peat archive at Walton Moss, Cumbria, England, The Holocene, 10, 465-479, 2000.

IPCC (Irish Peatland Conservation Council): Peatlands around the world (available at http://www.ipcc.ie/wptourhome1.html), 2000.
Kabata-Pendias, A. and Pendias, H.: Trace Elements in Soils and Plants, CRC Press, Boca Raton, 1992.

Kalviäinen, E. and Karunen, P.: On the growth, senescence, and decay-resistance of Spahgnum mosses, Proc. 7th Intern. Peat Congress. Dublin, 4, 263-275, 1984.

Keppler, F. and Biester, H.: Peatlands: a major sink of naturally formed organic chlorine, Chemosphere, 52, 451-453, 2003.

Khury, P. and De Vitt, D. H.: Fossil Carbon/Nitrogen ratios as a measure of peat decomposition, Ecology, 77, 271-275, 1996.

Lee, J. A. and Tallis, J. H.: Regional and historical aspects of lead pollution in Britain, Nature, 245, 216-218, 1973.

Létolle, R.: Nitrogen-15 in the natural environment, in: Handbook of Environmental Isotope Geochemistry, edited by: Fritz, P. and Fontes, J. Ch., 1 The Terrestrial Environment, Chapter 10, 407429, Elsevier, Amsterdam, 1980.

Macko, S., Entzeroth, L., and Parker, P.: Early diagenesis of organic matter in sediments. Assessment of mechanisms and preservation by the use of isotopic molecular approaches, in: Organic Geochemistry: Principles and Applications, edited by: Engel, J. M. H. and Macko, S. A., Plenum Press, New York, Chapter 9, 211-224, 1993.

Magny, M.: Lake-level fluctuations in the Jura and French subalpine ranges associated with ice-rafting debris events in the North Atlantic and variations in the polar atmospheric circulation, Quaternaire, 10, 61-64, 1999.

Magny, M.: Holocene climate variability as reflected by midEuropean lake-level fluctuations and its probable impact on prehistoric human settlements, Quatern. Int., 113, 65-79, 2004.

Magny, M., Bégeot, C., Guiot, J., and Peyron, O.: Contrasting patterns of hydrological changes in Europe in response to Holocene climate cooling phases, Quat. Sci. Rew., 22, 1589-1596, 2003.

Martínez Cortizas, A., García-Rodeja, E., Pontevedra Pombal, X., Nóvoa Muñoz, J. C., Weiss, D., and Cheburkin, A.: Atmospheric $\mathrm{Pb}$ deposition in Spain during the last 4600 years recorded by two ombrotrophic peat bogs and implications for the use of peat as archive, Sci. Tot. Environ., 292, 33-44, 2002.

Martínez Cortizas, A., García-Rodeja, E., and Weiss, D.: Peat bog archives of atmospheric metal deposition, Sci. Tot. Environ., 292, $1-5,2002$.

Martínez Cortizas, A., Mighall, T., Pontevedra Pombal, X., Nóvoa Muñoz, J.C., Peiteaddo Varela, E., and Piñeiro Rebolo, R.: Linking changes in atmospheric dust deposition, vegetation change and human activities in northwest Spain during the last 5300 years, The Holocene, 15: 698-706, 2005.

Martínez-Cortizas, A., Pontevedra-Pombal, X., García-Rodeja, E., Nóvoa-Muñoz, J. C., and Shotyk, W.: Mercury in a Spanish peat bog: archive of climate change and atmospheric metal deposition, Science, 284, 939-942, 1999.

Mason, R. P., Fitzgerald, W. F., and Morel, F. M. M.: The biogeochemical cycling of elemental mercury: Anthropogenic influences, Geoch. Cosmoch. Acta, 58, 3191-3198, 1994.

Mauquoy D., Engelkes, T., Groot, M. H. M., Markesteijn, F., Oudejans, M. G., van der Plicht, J., and van Geel, B.: High-resolution records of late-Holocene climate change and carbon accumulation in two north-west European ombrotrophic peat bogs, Palaeogeog. Palaeoclim. Palaeoecol., 186, 275-310, 2002.

Meili. M.: The coupling of mercury and organic matter in the biogeochemical cycle - towards a mechanistic model for the boreal forest zone, Water Air Soil Pollut., 56, 333-347, 1991. 
Mierle, G. and Ingram, R.: The role of humic substances in the mobilization of mercury from watersheds, Water Air Soil Pollut., 56, 349-357, 1991.

Mighall, T. M., Martínez Cortizas, A., Biester, H., and Turner, S. E.: Proxy climate and vegetation changes during the last five millennia in NW Iberia: pollen and non-pollen palynomorph data from two ombrotrophic peat bogs in the north western Iberian Peninsula, Rev. Paleobot. Palynol., 141, 203-223, 2006.

Mouline, C., Lambert, C. E., Dulac, F., and Dayan, U.: Control of atmospheric export of dust from North Africa by the North Atlantic Oscillation, Nature, 387, 691-694, 1997.

Myneni, S. C. B.: Formation of stable chlorinated hydrocarbons in weathering plant material, Science, 295, 1039-1041, 2002.

Norton, S. A., Evans, G. C., and Kahl, J. S.: Comparison of $\mathrm{Hg}$ and $\mathrm{Pb}$ fluxes to hummocks and hollows of ombrotrophic Big Heath bog and to nearby Sargent Mt. Pond, Maine, USA, Water, Air and Soil Poll., 100, 271-286, 1997.

Nriagu, J. and Pacyna, J. M.: Quantitative assessment of world contamination of air, water and soils by trace elements, Nature, 333, 134-139, 1988.

Ohlson, M. and Okland, R. H.: Spatial variation in rates of carbon and nitrogen accumulation in a boreal bog, Ecology, 79, 27452758, 1998.

Ohlson, M.: Spatial variation in decomposition rate of Carex rostrata leaves on a Swedish mire, J. Ecol., 75, 1191-1197, 1987.

Oldfield, F., Brown, A., and Thompson, R.: The effect of microtopography and vegetation on the catchtment of airborne particles measured by remanent magnetism, Quat. Res., 12, 326-332, 1979.

Pontevedra Pombal, X., Nóvoa Muñoz, J.C., García-Rodeja, E., Martínez Cortizas, A.: Mountain mires from Galicia (NW Spain), in: Peatlands: Evolution and Records of Environmental and Climate Changes, edited by: Martini, I. P., Martínez Cortizas, A., and Chesworth, W., Elsevier, Amsterdam, Developments in Earth Surface Processes 9, 85-110, 2006.

Pontevedra Pombal, X., Martínez Cortizas, A., and Buurman, P.: Las turberas de montaña de Galicia como sumideros de carbono, Edafología, 10(2), 1-10, 2004.

Prospero, J. M. and Lamb, P. J.: African droughts and dust transport to the Caribbean: climate change implications, Science, 302, 1024-1027, 2003.

Reimann, C. and de Caritat, P.: Distinguishing between natural and anthropogenic sources for elements in the environment: regional geochemical surveys versus enrichment factors, Sci. Tot. Environ., 337, 91-107, 2005.

Reynolds, B. and Fenner, N.: Export of organic carbon from peat soils, Nature, 412, 785-786, 2001.

Romero, D., Fraga Vila, I., and Sahuquillo, E.: Plant diversity in the Galician mire ecosystems (NW Iberian Penisula), IMCG Mires and Peatlands Field Symposium, Tierra del Fuego 2005, Argentina, 1-2, 2005.
Roos-Barraclough, F., van der Knaap, W. O., van Leeuwen, J. F. N., and Shotyk, W.: A Late-glacial and Holocene record of climatic change from a Swiss peat humification profile, The Holocene, 14, 7-19, 2004.

Scholtz, M. T., van Heyst, B. J., and Schroeder, W. H.: Modelling of mercury emissions from background soils, Sci. Tot. Environ., 304, 185-207, 2003.

Schroeder, W. H. and Munthe, J.: Atmospheric mercury- An overview, Atmosph. Environ., 32, 809-822, 1998.

Shotyk, W.: Atmospheric deposition and geochemical mass balance of major elements and trace elements in two oceanic blanket bogs, northern Scotland and the Shetland Islands, Chem. Geol., 138, 55-72, 1997.

Shotyk, W., Weiss, D., Appleby, P. G., Cheburkin, A., Frei, R., Gloor, J., Kramers, D., Reese, S., Van der Knaap, W. O.: History of atmospheric lead deposition since 12,370 14C yr BP from a peat bog, Jura Mountains, Switzerland, Science, 281, 1635$1640,1998$.

Tarnocai, C. and Stolbovoy, V.: Northern peatlands: their characteristics, development and sensitivity to climate change, in: Peatlands: Evolution and Records of Environmental and Climate Changes, edited by: Martini, I. P., Martínez Cortizas, A., and Chesworth, W., Developments in Earth Surface Processes, 9, Chapter 1 17-51, Elsevier, Amsterdam, 2006.

Thorndycraft, V. R. and Benito, G.: Late Holocene fluvial chronology of Spain: the role of climatic variability and human impact, Catena, 66, 34-41, 2006.

Updegraff, K., Pastor, J., Bridgham, S. D., and Johnston, C. A.: Environmental and substrate controls over carbon and nitrogen mineralization in northern wetlands, Ecol. Appl., 5, 151-163, 1995.

van Pée, K. H. and Unversucht, S.: Biological dehalogenation and halogenation reactions, Chemosphere, 52, 299-312, 2003.

Worrall, F., Burt, T., and Adamson, J.: Can climate change explain increases in DOC flux from upland peat catchments?, Sci. Tot. Environ., 326, 95-112, 2001.

Xia, K., et al.: X-ray absorption spectroscopic evidence for the complexation of $\mathrm{Hg}(\mathrm{II})$ by reduced sulfur in soil humic substances, Environ. Sci. Technol., 33, 257-261, 1999.

Yin, Y., Allen, H. E., Huang, C. P., Li, Y., and Sanders, P. F.: Adsorption of Mercury(II) by soil: Effect of $\mathrm{pH}$, chloride, and organic matter, J. Environ. Qual., 25, 837-844, 1996.

Yu, Z., Campbell, I. D., Campbell, C., Vitt, D. H., Bond, G. C., and Apps, M. J.: Carbon sequestration in western Canadian peat highly sensitive to Holocene wet-dry climate cycles at millenial timescales, The Holocene, 13, 801-808, 2003.

Zhang, Y. and Moore, J. Selenium fractionation and speciation in a wetland system, Environ. Sci. Technol., 30, 2613-2619, 1996. 